\title{
Review
}

\section{The misinterpellated subject}

\author{
James R. Martel \\ Duke University Press, 2017, xi + 328 pp., \\ ISBN: 9780822362968 (pbk.)
}

Contemporary Political Theory (2019) 18, S171-S174. https://doi.org/10.1057/s41296018-0213-8; published online 20 March 2018

James Martel's The Misinterpellated Subject attempts to productively expand upon Althusser's theory of interpellation through the development of the concept of 'misinterpellation.' Martel uses this concept to develop a critical mode of reading as part of an explicitly political project, which he links to anarchism. The book is lofty in its ambitions, but its most interesting aspects need excavating from underneath less compelling passages of literary criticism.

Martel presents his concept of misinterpellation as 'neither a defense nor a refutation... but a complication' of Althusser's theory of ideological interpellation (p. 21). Here the book hits its first major problem: For all of its centrality to his project, Martel's engagement with Althusser's theory is limited and superficial. The only work by Althusser that Martel cites is the essay on Ideological State Apparatuses (ISAs), despite the numerous other relevant works translated into English and published over the last few years (including On the Reproduction of Capitalism, from which Althusser's ISAs essay was excerpted). Curiously, Martel gets the name of the essay wrong. Althusser's essay is entitled 'Ideology and Ideological State Apparatuses (Notes towards an Investigation).' This essay is cited throughout Martel's book as 'Ideology and the State.' Martel's mis-citation turns out to be symptomatic: His version of 'interpellation' drops out apparatuses almost completely. While Althusser's 'interpellation' takes place in and through material practices embedded within material institutions ('apparatuses'), Martel's interpellation takes place in 'circuits' of assumption (p. 7), accusation (p. 199), anxieties (p. 247), projection and counterprojection (p. 39), and belief. Martel treats all firstperson forms of address (especially those within a text) as 'interpellations.' This apparatus-free version of interpellation means that Martel can see a subject's addressing herself in the first person as a form of self-interpellation, which is rather problematic (e.g., p. 88).

Martel's theory of interpellation is better read as a theory of recognition; he in fact suggests at one point that the Hegelian struggle for recognition is the basis of interpellation (p. 106). Interpellation for him works through the state's recognition

(c) 2018 Macmillan Publishers Ltd., part of Springer Nature. 1470-8914 Contemporary Political Theory Vol. 18, S3, S171-S174 www.palgrave.com/journals 
of subjects as legal persons (p. 36), and central to this process seems to be the assumption that the state is omniscient and 'know[s] who the subject 'really' is' (38). Martel's strategy for challenging and interrupting the workings of the dominant ideology will therefore be primarily directed against this assumption of an all-knowing state: 'to call the state's omniscience into question is to radically alter the way that power works' (p. 40). Whether or not Martel is trying to take creative liberties with Althusser's thought, this is far enough from the text that the Althusserian vocabulary becomes distracting rather than helpful.

Even disconnecting the concept of misinterpellation from any relation to Althusser, attempting to define or summarize the concept brings us up against a second major problem. By 'misinterpellation,' Martel seems to mean several very different things, and there does not seem to be a clear connection between the different meanings. First, misinterpellation covers circumstances where 'people respond to calls... that are not meant for them' (p. 4). Martel's historic examples include the Haitian revolution (responding to the call of the Declaration of the Rights of Man and of the Citizen) and various anticolonial movements at the end of World War I (responding to Wilson's 1918 'Fourteen Points' speech). Misinterpellation here refers to cases when marginalized people take seriously the universal discourse of rights, freedom, democracy, etc. - more seriously, in fact, than intended by its authors and orators. This form of misinterpellation is where Martel's work comes close to Althusser's student Jacques Rancière - who gets mentioned several times in Martel's book (e.g., pp. 97, 271), but never substantially engaged with. It would be interesting to see Martel develop this version of misinterpellation in dialogue with Rancière's theory of politics. For Rancière, this process involves the creation of a new, collective political subject. Martel briefly discusses collective political action (e.g., in chapter 6, where he defends a politics of 'conspiracy' rather than 'alliances'), but a specific theory of collective political agency is not articulated in the book. And while both thinkers espouse some kind of philosophical anarchism, one suspects there are significant - and potentially fruitful - disagreements between Martel and Rancière about what anarchic politics looks like.

A very different kind of 'misinterpellation' involves throwing off unified subjectivity in favor of a decentralized, multiple subjectivity. Because Martel's interpellation is psychological rather than social, it confers subjectivity rather than mere subjecthood. Interpellation is therefore not simply a matter of taking on various kinds of social agency, but of taking up a unified subject position; Martel equates this psychological subjectivity with the liberal subject. Challenging hegemonic liberalism can therefore consist of rejecting our identities as unified, self-consistent subjects. This misinterpellated subject's 'very being has been decentralized. Rather than having one core and centralized subject, each of us becomes many voices, many overlapping and mutually entangled "selves" (p. 160). In short, Martel seems to argue for some kind of psychosis or schizophrenia 
as a radical response (and alternative) to liberal capitalism. It is surprising that Deleuze and Guattari receive only brief mention, and always with reference to the idea of 'minor literature'; neither Anti-Oedipus nor A Thousand Plateaus is referenced. Nor, in fact, does Martel seem to be aware that his call for 'misinterpellated subjectivity' champions schizophrenia. One of his major examples of this kind of misinterpellation is Bess from Lars von Trier's Breaking the Waves, and Martel acknowledges that Bess seems schizophrenic, but does not seriously work through the implications of this issue. Indeed, at a later point, Martel writes that 'although Bess certainly appears to be crazy... she can be read as the only truly sane person in the film' (p. 250). This is a far cry from Deleuze and Guattari's explicit development of schizophrenia as a theme; in the absence of such a conscious development, the apparent psychosis of Martel's misinterpellated subjects starts to look like a potential objection - one which simply 're-reading' the subjects in question as sane does not fully dispel.

Unfortunately, the issue of 're-reading' is central to The Misinterpellated Subject, and it is where we find a third problem. One way of describing Martel's project (p.266) is to see him developing a mode or practice of 'misinterpellated reading' (p. 213). But the ambiguity of the concept of misinterpellation spills over into our understanding of 'misinterpellated reading': Martel never lays out specifically what he means by 'misinterpellated reading,' what kind of practice it is, and how it differs from other kinds of critical reading (say, symptomatic reading, one obvious example). Early on, he describes misinterpellated reading as reading 'against the grain, in tension with established authorities and figures in the novel and even with the way the novel seems to insist on being read' (p. 11). But even this generic statement is undermined by two features of Martel's analyses. First, Martel rarely engages with any secondary literature. We might see better what a 'misinterpellated reading' does if we saw how it leads us to a different reading than the standard. Second, Martel does not explain how he arrives at many of his conclusions (e.g., 'The Lighthouse, it seems, is the source of interpellation; the stand-in or personification of God in this novel.' p. 176), and so his examples of 'misinterpellated reading' lack the kind of rigor that would reveal their usefulness.

Given that Martel's concern is with anarchism, the book would be dramatically improved by dropping the underdeveloped theory of misinterpellated reading, which ultimately only serves as a series of examples. Rather than providing readings of novels and memoirs, Martel would be better served by engaging with political theory more directly. Likewise, rather than Althusser, it seems to me that Deleuze, Guattari, and Lacan would have been better interlocutors. (One is tempted to say Althusser is Martel's misinterpellated subject: Althusser is not the theorist who should have been in this book, but he is the one who showed up anyway.) This 'decentralized' form of misinterpellation is the most interesting and the one that ties in best with Martel's anarchism. Like Anti-Oedipus, Martel's project can be read as a book of ethics, in this case an anarchist ethics. He is interested in 'the

(c) 2018 Macmillan Publishers Ltd., part of Springer Nature. 1470-8914 Contemporary Political Theory Vol. 18, S3, S171-S174 S173 
anarchism of the soul or subject as a necessary complement to the anarchism of the city or community' (p. 30). This 'anarchism of the soul' is a way of thinking about what it means, as Martel puts it, 'to be anarchist "all the way down", down to our very psyches' (p. 160). The stakes of Martel's project - and the really compelling questions at the heart of his work, I think - crop up almost in passing in his analysis of Bess: 'What does it mean to be 'oneself' when we are... overlapping jurisdictions of personhood and identity?' (p. 262). There is really an interesting set of questions here, and a project that could be developed further. Alas, that project is buried in The Misinterpellated Subject: beneath a mis-interpolated Althusserian vocabulary, an underdeveloped mode of reading, and rather distracting literary and film criticism.

Matthew Lampert

Wheeling Jesuit University, Wheeling, WV 26003, USA mlampert@wju.edu 